that expansion of services which would be rendered possible by an increase in its membership to include every chemical manufacturer in Great Britain. In his speech at the annual general meeting held on October 8, the chairman referred to the successful outcome of many of the enterprises which the Association has undertaken in the interests of its members, including in his survey a reference to the measures which are being undertaken to protect our factories against air attacks in the unfortunate event of war. The Association has also participated in investigations concerning the detection of toxic gases in industry. It is announced that the first pamphlet of the series, that dealing with hydrogen sulphide, will shortly be published by the Department of Scientific and Industrial Research. Dr. E. F. Armstrong was re-elected president for the coming year.

\section{The Velocity of Light}

From time to time, Mr. M. E. J. Gheury de Bray has published in the columns of NATURE communications on this subject. He has now brought together the results of his investigations in an article published in Isis (25, 2; September 1936), entitled "The Velocity of Light: History of its Determination from 1849 to 1933". Reprints of the article have been prepared and can be obtained from Mr. Gheury de Bray, Imperial Patent Service, First Avenue House, High Holborn, W.C.1 (price 1s.).

\section{Pavlov Institute of Aviation Medicine}

As successful flying over long distances or to high altitudes depends not only on the efficiency of the aeroplane and the skill of the pilot but also to some extent on such minor details as the clothing and diet of the pilot, the structure of the cabin, etc., an Institute of Aviation Medicine dedicated to Prof. I. P. Pavlov was organized about a year ago in Soviet Russia. The laboratories of the Institute make tests of clothing, oxygen apparatus and anti-noise helmets, and study the problem of producing light, warm and comfortable clothing for airmen. Oxygen apparatus used in flights is produced under the direct supervision of the Institute, and the fitness of airmen wishing to ascend to high altitudes is tested in the Institute's barometric chamber.

\section{Early Photographic Instruments}

Some of the earliest instruments in the history of photography have just been acquired by the Science Museum, South Kensington, on loan from the Royal Photographic Society of Great Britain. They include three instruments used by Fox Talbot, the inventor of the first paper photographic process : (1) A camera lucida, the use of which on the shores of Lake Como in 1833 first suggested to him that the invention of a sensitive paper would record such scenes more perfectly than sketches made by hand. This is the instrument mentioned in his "Pencil of Nature", published in 1844. (2) Fox Talbot's solar microscope, with which the earliest photomicrographs on paper were produced. (3) A Culpepper type microscope, c. 1820. With other instruments and specimens which have recently been acquired and are in course of classification prior to exhibition, the representation of Fox Talbot's work in photography bids fair to be complete.

\section{"Annual Tables of Constants and Numerical Data"}

THe publication of the "Annual Tables" having lagged behind schedule since vol. $10(1930)$, the new managing committee (Institut de Chemie, 11 Rue Pierre Curie, Paris, $\left.5^{\mathrm{e}}\right)$ proposes to make up for it by publishing the data for 1931-36 in a more condensed form and more critically edited, in separate fascicules by subjects, partly separately for 1931-34 and 1935-36 and partly for the whole period 1931-36. The set of these fascicules will form vols. 11 and 12 of the "Annual Tables". 'This programme is to be completed in 1937: the numerical material published in the "Annual Tables" will then be brought up to date. In addition, an index volume by substances for vols. 6-10 (1923-30), like that published for vols. 1-5 (1910-22), is to appear towards the end of this year. A new index volume by substances will be prepared for vols. 11 and 12 , to be published in 1937. The Committee would welcome inquiries about the "Tables", and state that the back numbers have now been greatly reduced in price. The new fascicules are being issued at a very modest price, which will place them at the disposal of all scientific workers likely to need them in their investigations. The preparation of the "Annual Tables", which is a purely scientific and non-profit-making undertaking, is a worthy task deserving the active support of men of science in securing their prompt publication.

\section{Dr. A. H. Mackenzie}

IN announcing the death of Dr. A. H. Mackenzie, in NATURE of October 10, he was described, following "Who's Who", as "Pro-Vice-Chancellor of the Osmania University, Hyderabad". Prof. M. S. Ahmed writes to say that the correct official title is "Pro-ViceChancellor of and Special Propagandist for the Osmania University of Hyderabad". He adds : "Dr. Mackenzie was appointed to the position of ProVice-Chancellor of the Osmania University in which capacity he had to work six months in the year at Hyderabad, and the remaining six months he had to spend in Great Britain in doing special propaganda in the British Universities on behalf of the Osmania University".

\section{A Nova in Sagittarius}

THE discovery of a nova on October 6 (the third to be discovered since last June) has been announced by telegram from the International Astronomical Union's Bureau at Copenhagen. The position is given as R.A. $18^{\mathrm{h}} 4 \cdot 5^{\mathrm{m}}$ : Dec. $34^{\circ} 21^{\prime}$ south : magnitude 6 on Oct. $6^{\text {d }} 0^{\mathrm{h}}$ U.T. This position places the nova in the constellation of Sagittarius and roughly midway between the 3rd magnitude stars, $\gamma$ Sagittarii and $\eta$ Sagittarii. The discoverer is Mr. C. Jackson, 
of the Union Observatory, Johannesburg, who less than a month ago discovered a faint comet (1936 c). Owing to its southern declination of $-34^{\circ}$, it will not be possible to observe the nova from the latitude of Greenwich, and further news of its behaviour must be awaited from southern observatories.

\section{Announcements}

The Royal Society of New Zealand has awarded the T. K. Sidey Summer-Time Memorial Medal and Prize for 1936 to Sir Leonard Hill. This award, which consists of a gold medal and $£ 100$ in New Zealand currency, is made to the person who in the opinion of the Council of the Society has made a valuable contribution to human knowledge by original research into the effect of light and solar radiations on human comfort.

The Huxley Memorial Lecture of the Royal Anthropological Institute will be delivered in the rooms of the Royal Society on October 27 by Prof. E. Westermarck, who will take as his subject "Methods in Social Anthropology".

THe following appointments and promotions in the Colonial Service have been made: H. M. James, to be agricultural superintendent, Cyprus; C. H. F. Walker, to be agricultural officer, Nigeria; J. M. Waterson, to be plant pathologist, Agricultural Department, Bermuda ; C. J. Taylor, to be assistant conservator of forests, Gold Coast; J. A. Allan, to be lecturer in botany, chemistry and physics, Department of Science and Agriculture, Barbados; L. P. Henderson (late agricultural officer), to be agricultural officer, Nigeria ; Capt. J. R. Mackie (assistant director of agriculture), to be director of agriculture, Nigeria; F. B. Notley (entomologist, Kenya), to be entomologist, Agricultural Department, Tanganyika ; D. F. Chesters (senior assistant conservator of forests), to be conservator of forests, Nigeria ; Dr. J. C. Tull (Government pathologist and professor of pathology, Straits Settlements), to be pathologist, Cyprus; S. G. Willimott (Government analyst, Cyprus), to be assistant Government analyst, Straits Settlements.

THE Institute of Hygiene of Czechoslovakia is carrying out important studies in connexion with vitamins in the diet of the poor, especially in winter, when most of their food contains only a very small quantity of antiscorbutic principles.

THE central administration of the perfumery and cosmetics industry of the U.S.S.R. is to open an Institute of Cosmetics and Hygiene at Moscow in November. The Institute will consist of three departments devoted respectively to cosmetics, physiotherapy and plastic-therapeutic gymnastics, with a staff of specialists in dermatology and physical therapy.

WE are asked to state that the address of the publisher of "The Way to Happiness for Humanity" noticed in Nature of October 10 (p. 636) is 93 Braybrook Street, London, W.12.
Messrs. Willibald Keller, Hindenburgstr. 94, Leipzig, are issuing shortly a new edition of the classical work "Die Alpen im Eiszeitalter" by Albrecht Penck and Ed. Bruckner. The new edition will con. tain an additional chapter in which Albrecht Penck has given a survey of the present development of knowledge of the glacial period and the progress since the publication of the first edition. The subscription price of the work, consisting of three volumes, is 66 gold marks until November 30 .

Applications are invited for the following appointments, on or before the dates mentioned:

One resident engineer, two senior engineers and one junior engineer for airport constructionSecretary, Office of Public Works, Dublin (October 21).

An assistant engineer in the Ministry of TransportEstablishment Officer (October 21).

A records officer in the office of the Industrial Research Council of the Department of Industry and Commerce, I.F.S.-The Secretary, Civil Service Commission, 45 Upper O'Connell Street, Dublin, C.8 (October 22).

A junior assistant in the Department of Civil Engineering, Queen's University, Belfast-Prof. Hummel (October 23).

A teacher in engineering and an engineering workshop instructor at the Kenrick Technical College, West Bromwich-Director of Education (October 23).

A technical assistant (electrical, mechanical and civil engineering industries) for a War Department inspection establishment at Woolwich-UnderSecretary of State (C. 5), War Office, London, S.W.1 (October 24), quoting "Appts./1".

An assistant director of horticultural education and an agricultural advisory officer to the Norfolk County Council--The Clerk, The Shirehouse, Norwich (October 24).

Two assistant drainage engineers in the Ministry of Agriculture and Fisheries-Secretary (October 26).

A public analyst to the Metropolitan Borough of Chelsea-Town Clerk (October 29).

A professor of philosophy and a lecturer in the Department of Education and Philosophy, Canterbury University College, Christchurch, New Zealand -Secretary, Universities' Bureau, 88A Gower Street, London, W.C.I (October 31).

A lecturer in the Department of Pathology, University, Birmingham-Secretary (October 31).

A head of the Science Department, West Ham Municipal College - Town Clerk and Education Officer, West Ham (November 6).

An assistant curator (male) at Somerset County Museum, Taunton Castle-The Curator.

A civil engineer for the Public Works Department, Government of North Borneo-Secretary, British North Borneo (Chartered) Company, Staple Hall, Stone House Court, Bishopsgate, London, E.C.3.

Civil engineering and architectural assistants in the Drawing Office, H.M. Dockyard, Portsmouth-Civil Engineer-in-Chief, marked "D.O. Assts., Portsmouth" 